DOI: 10.20472/EFC.2018.010.024

\author{
MICHAL MARES \\ University of Economics, Prague, Czech Republic \\ MARTIN SLANY \\ University of Economics, Prague, Czech Republic
}

\title{
EARLY WARNING INDICATOR OF FINANCIAL CRISES FOR V4 COUNTRIES
}

\begin{abstract}
:
This paper represents an early warning indicator of financial crises applied to the data of the Czech Republic, Poland, Hungary and Slovakia (V4 counties) between 2005 and 2018. Based on the previous research, 16 indicators were selected to build up the composite indicator of cyclical components - so. Composite Index of Financial Instability (CIFI), and discussed its development. The relevance of the presented indicator, especially in the context of the Euro-American financial crisis of 2008-2009, is demonstrated in both graphical and econometric analysis using panel logistic regression. The conclusion implies that all V4 countries had experienced a high instability in connection with the global financial crisis 2008/2009 and implies different developments in financial conditions in recent years. The output of econometric model confirms positive relation between the value of $\mathrm{CIFI}$ and probability of financial crises occurrence. An increase in the CIFI per unit indicates an increase in probability of occurrence crisis approximately by $7 \%$. In spite of all its limitations, the usefulness of the composite index in the context of economic policymaking is proven by the analysis.
\end{abstract}

\section{Keywords:}

financial crises, early warning indicator, composite index, Visegrad countries, panel regression

JEL Classification: C53, E47, G01 


\section{Introduction}

With the advent of the global or rather Euro-American financial and economic crisis of 2008/2009, interest in analyzing the financial crisis has increased again after it receded during the Asian and East European financial crises of the second half of the 1990s. Even before the advent of the most significant post-war recession, many studies have shown that the rise of globalization in recent decades has increased the frequency, breadth, and depth of the impact of financial crises in the economy, both between developing and developed economies. Concerning the relatively broad definition of the very concept of a financial crisis (Bordo 2007), the number of identified crises is quite different. For example, Laeven and Valencia (2008) marked nearly four hundred of them only in the 2008/2009 Euro-American crisis for the past four decades.

Due to the renewed interest in the financial crisis, interest in anticipating financial crises and the early warning system also increased. While the first generation of the financial crisis models of the late 1970s (referred to as models of current account balance crises) allowed relatively simple predictions based on detection of the development of a few economic variables; second and third generation models lost this simple ability of prediction. Issues of multiple balance, the existence of sudden crises triggers, the impact on a country even without the bad economic fundamentals or the broader concept of the financial crisis - all of these make predicting financial crises difficult. Despite the complexity of this phenomenon, one of the most reliable indicators of the financial (and subsequent economic) crisis is the sharp increase in the volume of credit and asset prices in the economy. Borio and Lowe (2002) report that nearly 80 percent of previous crises can be predicted on a one-year horizon by credit growth. Similar findings, accompanied by the rise in property prices, are also reported in recent studies such as Cardarelli, Elkdag and Lall (2009). Dell'Ariccia et al. (2013) state that not all the sharp rises in asset prices ends with the crisis, but the probability of the crisis is growing sharply with the economic boom in which asset prices are rising.

Financial crises are at the forefront of the interests of economists and economic policymakers, especially because of their impact on the real economy. And the EuroAmerican crisis has reinforced this idea. For example, the Laeven and Valencia studies (2013) estimate that the cumulative loss of only banking crises was on average 23 percent of GDP in the first four years over the past decades.

Abiad et al. (2013) estimate the loss of the product seven years after the financial crisis at 10 percent of GDP. The median cumulative loss of the recent Euro-American crisis amounted to 33 percent of GDP in developed countries and 26 percent in developing economies. The study by Kose, Loungani, and Terrones (2013) estimates a decline in world GDP per capita caused by the recent Euro-American crisis at a rate of 2 percent. The goal of the following article fits into the analysis of the early warning system of the financial crisis. The aim is to indicate imbalances in the economy that would increase the risk of the 
financial crisis. A composite leading indicator, comprised of the most relevant indicators, will be created and will be applied to Visegrad Four countries' data in 2005-2018, especially in the context of the Euro-American financial crisis and current post-crisis developments. The results will also be compared with their most important business partner - Germany. The relevance and statistical robustness of this composite indicator, which we call the composite indicator of financial instability (CIFI), will be tested by econometric analysis using panel logistic regression on a group of EU countries over a long period of forty years 1970-2010.

\section{Definition of method of analysis}

Although over the past thirty years, individual approaches to understanding the financial crisis have been converging, there are still significant differences in the definition of the financial crisis. There is a consensus that for financial crises, it is essential that the causes of economic problems are not found in the real economy, but they arise in the financial system, but they are generally seen as a systemic crisis of the entire financial system, with significant impacts on the real economy. Most commonly, authors (such as Bordo, 2007) understand these types of financial crisis: the currency crisis, the banking crisis, the twin crisis, the debt crisis, the systematic crisis.

In general, the authors attempt to indicate the financial crisis using two main methods - the signal approach and the econometric approach. (I) The signaling method seeks to measure the non-parametric estimation of the risk of the financial crisis. The essence is to evaluate the usefulness of given indicators for signaling a potential crisis. Thresholds are selected for each indicator so that there is a balance between the risk of many false alarms and the risk of failure to predict the crisis. This method was used, for example, by Kaminsky and Reinhart (1999) or Edison (2000); and they were one of the first ones who used it. Under the signaling method, we can also include the creation of composite indicators, which are different combinations of individual indicators (variables). For example, Kaminsky and Reinhart (1999), Slaný (2010), Babecký et al. (2011) and Vermeulen et al. (2015) use composite indicators or indexes in their works. (ii) In contrast, the econometric approach is multidimensional and allows, for example, testing the statistical significance of the selected explanatory variables. Most often, regression estimates or probit or logit models are used to test the suitability of each parameter. An econometric approach can be found, for example, by Babecký et al. (2011), Vermeulen et al. (2015) or Frankel and Saravelos (2011).

Our approach to the analysis of financial imbalances is based on the signaling method, respectively, on the usage of our own Composite Indicator of Financial Instability, supplemented by an econometric approach, when verifying the statistical credibility of a composite indicator. 
The following steps were taken to build the composite lead indicator:

1. selecting the analyzed sample of countries and the reference period;

2. selecting appropriate partial indicators;

3. editing individual time series data;

4. obtaining cyclical components from time series of individual sub-indicators;

5. data normalization;

6. summing normalized data in absolute values.

The result is the composite financial imbalance index (CIFI). It does not have the ambition to be a full predictor model. It is rather a post factum analysis based on a simple empirical approach, where the growth of value indicates increased financial sector instability and increased probability or risk of financial crisis.

\section{Creating a composite indicator}

\subsection{Sample countries and the reference period}

The text focuses on a relatively homogeneous group (geographically, historically, economic structure, institutional environment) of the so-called Visegrad Four (Czech Republic, Slovakia, Poland, Hungary. These countries joined the European Union in 2004 and their most important trading partner is Germany (for all V4 countries, Germany is the first country in the amount of both export and import). Germany also serves as a reference country. The data will be monitored for the period 2005-2018. Choosing the length of the time series is not random since one of the objectives of this paper is to compare the size and length of the imbalance during the Euro-American financial crisis with the current developments, when all economies show a relatively long-term economic conjunction.

\subsection{Selection of indicators}

Since the mid-1990s, there have been a number of texts that seek to develop techniques to predict financial crises. Pioneer works are Frankel and Rose (1996) and Kaminsky and Reinhart (1996) and the International Monetary Fund publication. There are a number of monitored indicators and individual empirical studies differ significantly in their choice and importance in predicting the crisis. Yet, there are several indicators with broad consensus. Three major studies (Kaminsky, Lizondo and Reinhart 1998, Hawkins, Klau 2000, and Abiad 2003) contributed to this topic through a review of 76 studies covering the crisis between 1950-2002. The study by Frankel and Saravelos (2011) supplemented this sample with another 7 studies published between 2002-2009. The main measure for our choice will be not only how often this indicator has been used in these studies, but also how often it has been found to be statistically significant. Frankel and Saravelos (2011) will 
serve this purpose. The studies of these authors are based on studies from 1950-2009. Their results show that the most common statistically significant indicators are foreign exchange reserves, real exchange rates, loan volume, GDP and current account balance. Foreign reserves were found to be significant even in 50 of 83 studies and the real exchange rate was found to be significant in 48 studies. There is a consensus in the literature that an effective early warning system should include a wide range of different indicators. Financial crises usually precede multiple financial, monetary, economic and sometimes political problems. It is mostly a combination of domestic and foreign imbalances that will affect both the financial sector and the real economy. Our approach will also be based on a study by Goldstein and Turner (1996), which concludes that the volatility of macroeconomic variables may be one of the causes of the financial crisis. This can be the cause of the crisis itself. We identify with this point of view, also considering the development of financial and economic crises in the 1990s and 2008/2009 in the Central European region under review. Therefore, their importance in our composite indicator will be relatively significant.

Taking into account the above, the following variables were used, these sub-indicators (descriptive statistics are given in Annex 1). Data sources were the IMF, OECD and Eurostat databases.

- the volume of reserves (reserves), in millions of USD. The decline or increase in foreign exchange reserves may indicate the implementation of foreign exchange interventions by the central bank with the aim of maintaining a firm rate or exchange rate commitment.

- the real effective exchange rate $(R E E R)$. The real exchange rate was deflated by the consumer price index, taking into account the weights of foreign trade turnover. REER is a key factor influencing the export of domestic products and services. The appreciation of the REER may reflect the appreciation of the nominal exchange rate or the growth of the domestic price level as compared to foreign ones, and thus the decline in the competitiveness of domestic goods and the deterioration of the balance of payments (and vice versa).

- Gross domestic product (GDP). GDP measured at market domestic prices and quarter-on-quarter real GDP growth. Strong and stable economic growth reduces the probability of a crisis.

- the volume of credits in the economy (credit_GDP) expressed in relation to the GDP. The rapid increase in the volume of provided credits is very often accompanied by lower claims on the applicants' creditworthiness, which may lead to an increase in outstanding loans and a subsequent financial crisis. 
- The current account balance of payments deficit $(C A)$ expressed in nominal domestic prices: the current account balance of payments deficit or a sharp drop in surplus indicates the appreciation of the currency or the growth in domestic price levels.

- Then indicators of the openness of the economy were used, such as the volume of export and the volume of import, measured in nominal domestic prices, exports of goods and services to GDP ratio, exports of goods and services to GDP ratio, in percent. All V4 countries (with the relative exception of Poland) are among the small and large open economies.

- the consumer price index $(C P I)$ in percent. A high rate of inflation may indicate the expansionary policy of the central bank and the subsequent imbalance in the economy.

- the industrial producer price index $(P P I)$ in percent. The Industrial Producer Price Index measures over time the relative changes in the prices by which producers value the domestic production. The index is focused on goods produced in the domestic market and destined for domestic sales and does not include the movement of prices for products destined for export.

- the stock index generally reflects the mood of investors in the financial market. The rapid growth in the asset markets and their subsequent fall is very often linked to the financial crisis.

- the price developments in the real estate market (house_price) defined as changes in the prices of all types of real estate purchased by households. The index only considers market prices and does not include so-called self-help buildings.

- Then the short-term interest rate was used (IR_sr) expressed as a 3-month interest rate on a particular money market, and the long-term interest rate (IR_Ir) expressed as the average interest rate of government bonds with a 10-year maturity. The rapid change in short-term interest rates is a potential signal for the defending of local currency by the national bank or it provides information about the central bank's attempt to correct a sudden imbalance in the economy through the basic monetary policy instrument. Long-term rates are one of the determinants of business investment.

\subsection{Data editing}

The acquired time series must be not only long enough but also with sufficiently high frequency (Vermeulen et al., 2015) and internationally comparable. Our approach includes quarterly data from five countries, which are analyzed using 16 indicators based on quarterly data from the first quarter of 2005 to the first quarter of 2018. Unlike annual data, quarterly data also takes into account sudden fluctuations of variables and better reflects the development of sentiment of economic subjects in the economy. 
Several problems occurred during the compilation of the dataset. The first problem was that several observations within the time series were missing. If, however, only a few individual observations are missing in the time series, and the time series is sufficiently long, the linear interpolation method to calculate missing observations is generally recommended in the literature (Vermeulen et al., 2015). Another complication was the unavailability of some data in the seasonal adjustment. Seasonal cleaning was therefore done using the "X13-ARIMA" method in the EViews statistical software.

\subsection{Getting cyclical components and data standardization}

The composite indicator of the financial imbalance (CIFI) was grasped as an indicator of the composite cyclical component of all of the above sixteen indicators, which means the deviation of the partial indicators from their long-term trend. The cyclic component was obtained by the Hodrick-Prescott filter method (Hodrick and Prescott, 1997). This is one of the most used methods for decomposing the time series into a trend and cyclical component. ${ }^{1}$ The cyclic components were then standardized using the standardization method, according to the following formula (1):

$$
x_{i}^{\prime}=\frac{x_{i}-\mu(\mathrm{X})}{\sigma(X)}
$$

where $x_{i}$ represents the actual value of the time series $X, \mu(X)$ represents the arithmetic mean, and $\sigma(X)$ the standard deviation of the time series $X$ and $x_{i}^{\prime}$ is then the normalized value.

The time series after standardization shows a standard deviation of one and zero scattering. This allowed the time series of individual different financial and macroeconomic indicators to be compared and added to each other (see OECD, 2008). The absolute values of the deviations were used in the calculations, as both the positive and the negative value fluctuations are considered to be imbalances (the search for stability). The individual indicators are used with the same weight in the resulting composite indicator. The unweighted average is easily interpretable (Vermeulen et al., 2015), and weighing does not bring much better results (Illing and Liu 2006).

This composite indicator, respectively, the composite indicator of the cyclical component of the given indicators has several advantages over analyzing only the deviations of individual indicators. By its very nature, it eliminates the fluctuations of one of the indicators, while others would show standard behavior. Another advantage is its easy interpretation since it only gains positive values for a given country at a certain interval, and the higher

\footnotetext{
1 The value of $\lambda$ was chosen 1600 , which is in compliance with the fact that the data used is of a quarterly character.
} 
the number is, the higher is the probability of the financial crisis, respectively, the rise in values means an increase in financial instability, financial strain. The composite index can also be easily compared in time and also between countries, which is the purpose of this text.

\section{Results}

The relevance of the introduced index is tested both on the basis of graphical analysis and by a more sophisticated method. With respect to the use of the dummy dependent variable, the panel logistic regression method is used for the estimate. As a dependent variable, the time series published in Babecký et al. (2011) was used, containing a quarterly database of financial crises on a sample of $40 \mathrm{EU}$ and OECD countries. The financial crisis is indicated (crises $=1$ ) if confirmed by at least one economic study and confirmed by a survey among experts mainly from local central banks. The same approach is used by the work of economists Vermeulen et al. (2015).

Table 1: Panel logistic regression output

$\begin{array}{lll} & \text { LR chi2(1) } & =17.63 \\ \text { Log likelihood }=-\mathbf{3 6 1 . 5 4 5 2 9} & \text { Prob }>\text { chi2 } & =0.0000\end{array}$

\begin{tabular}{r|rrrrrr}
\hline crises & OR & Std. Err. & $z$ & $P>|z|$ & [95\% Conf. Interval] \\
\hline CIFI & 1.074745 & .0182063 & 4.26 & 0.000 & 1.039647 & 1.111028 \\
\hline
\end{tabular}

Source: STATA estimation

Panel logistic regression results are available in the table 1. P-value of the CIFI variable equals zero so we can reject the null hypothesis and say that the coefficient is significantly different from 0 . The output confirms the positive relationship between the value of CIFI and the probability of financial crises occurrence. According to the final odds-ratio (1.07), the relationship can be interpreted as following. An increase in the CIFI per unit indicates an increase in the probability of the occurrence of a crisis approximately by $7 \%$. A probability development for analyzed countries is shown in graph 1. 


\section{Graph 1: Probability development for V4 countries + Germany}

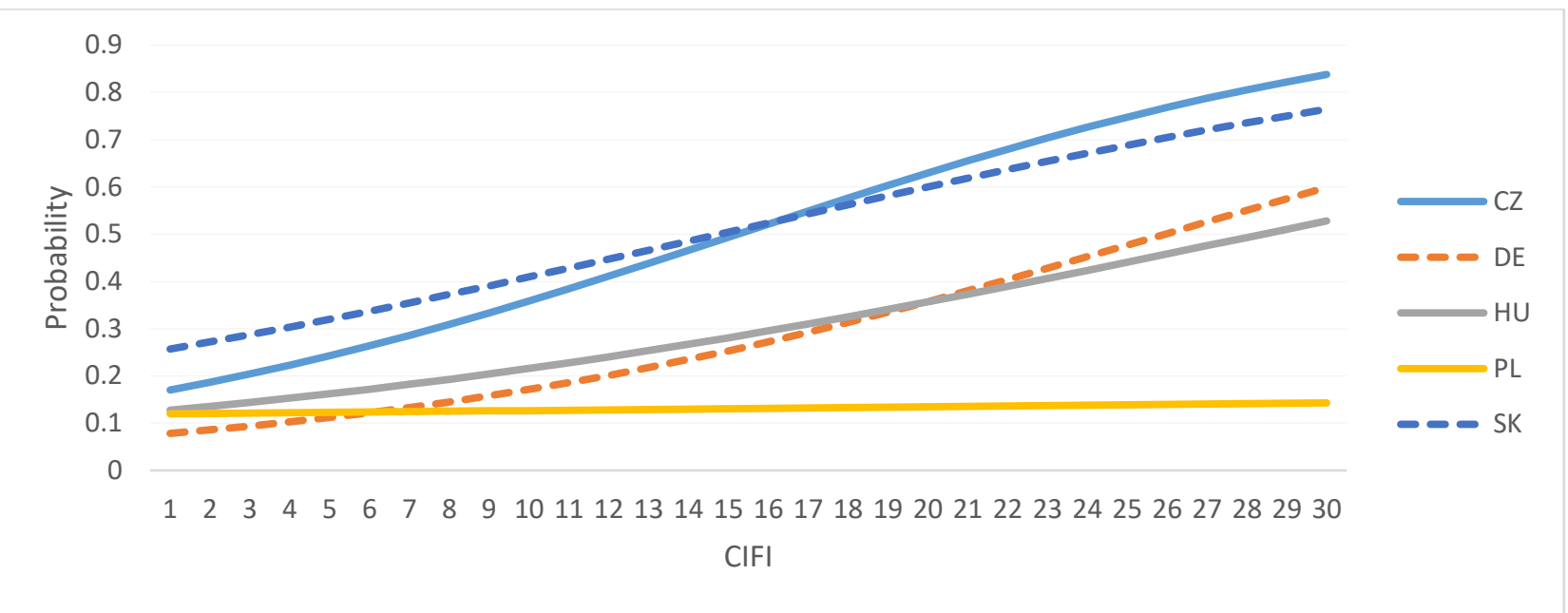

Source: STATA estimation

The following five graphs show the resulting values of our composite indicator financial imbalances (CIFI).

The Czech Republic (graph 2): The indicator had already signaled an increased potential financial instability since 2007, culminating in the first quarter of 2008. The peak of the indicated instability occurred before the subsequent financial crisis (early September 2008) was imported into Europe and before the financial and economic crisis was imported into Europe. After a slight decline in mid-2008, the index started to rise again to its peak in the first quarter of 2009 (17). Then the index stabilized (the Czech economy experienced the longest stagnation in its history). Then the indicator indicates an increase in instability since the end of 2013 - which is, in our opinion, the most affected by foreign exchange interventions by the CNB (the Czech National Bank), which has increased the potential instability in the future. Since then, with moderate fluctuations, the indicator is growing. Currently, the indicator is similar to the peak of the boom at the turn of the years 2007 and 2008. 


\section{Graph 2: The CIFI results for the Czech Republic}

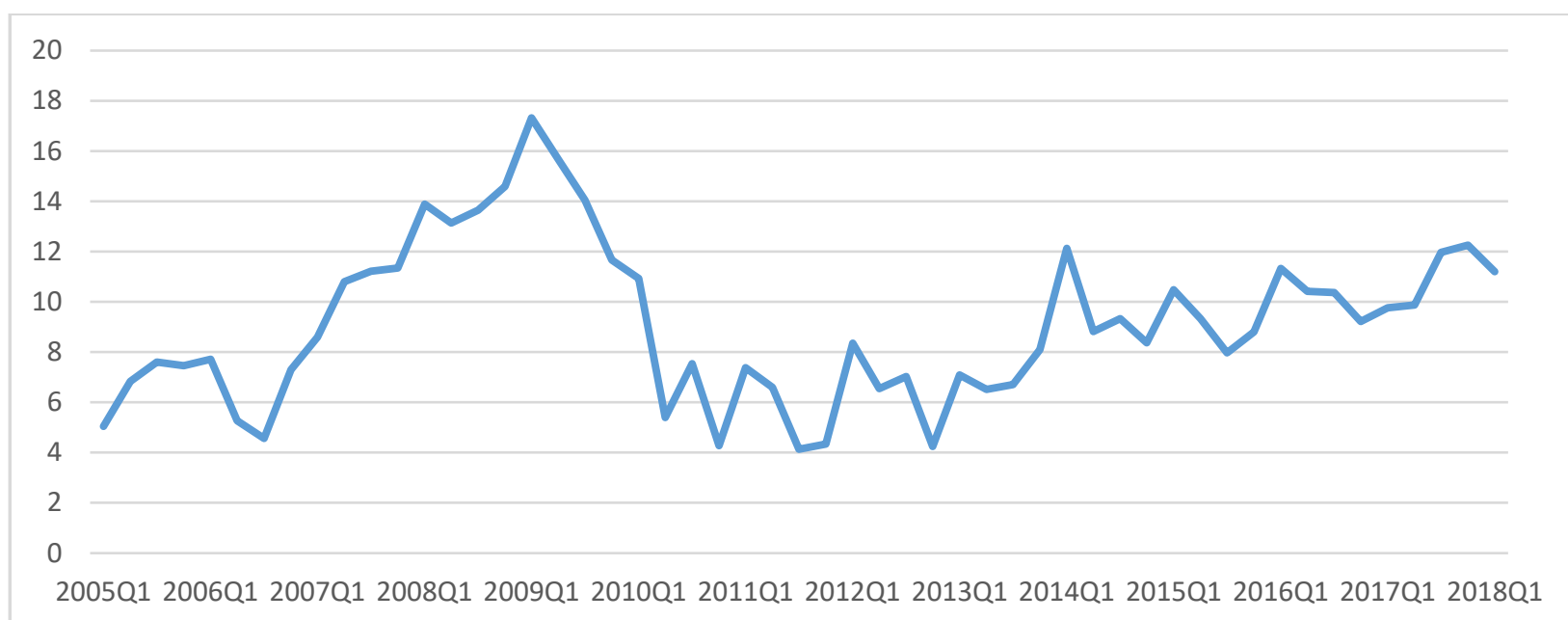

Source: STATA estimation

Slovakia (graph 3): The composite indicator indicates an increase in instability already in 2006, but similar to the Czech Republic, it culminates at the turn of the years 2007 and 2008 when the Slovak economy showed a significant imbalance (index value 17). Unlike the Czech Republic, in the pre-crisis period, a characteristic decrease in imbalances (decrease in indicator values) occurred. With the start of the economic crisis and the subsequent recovery, the index is continually returning to trend values, a slight increase in instability can be observed in the first half of 2012 and at the turn of the years 2015 and 2016, but the trend is declining.

\section{Graph 3: The CIFI results for the Slovakia}

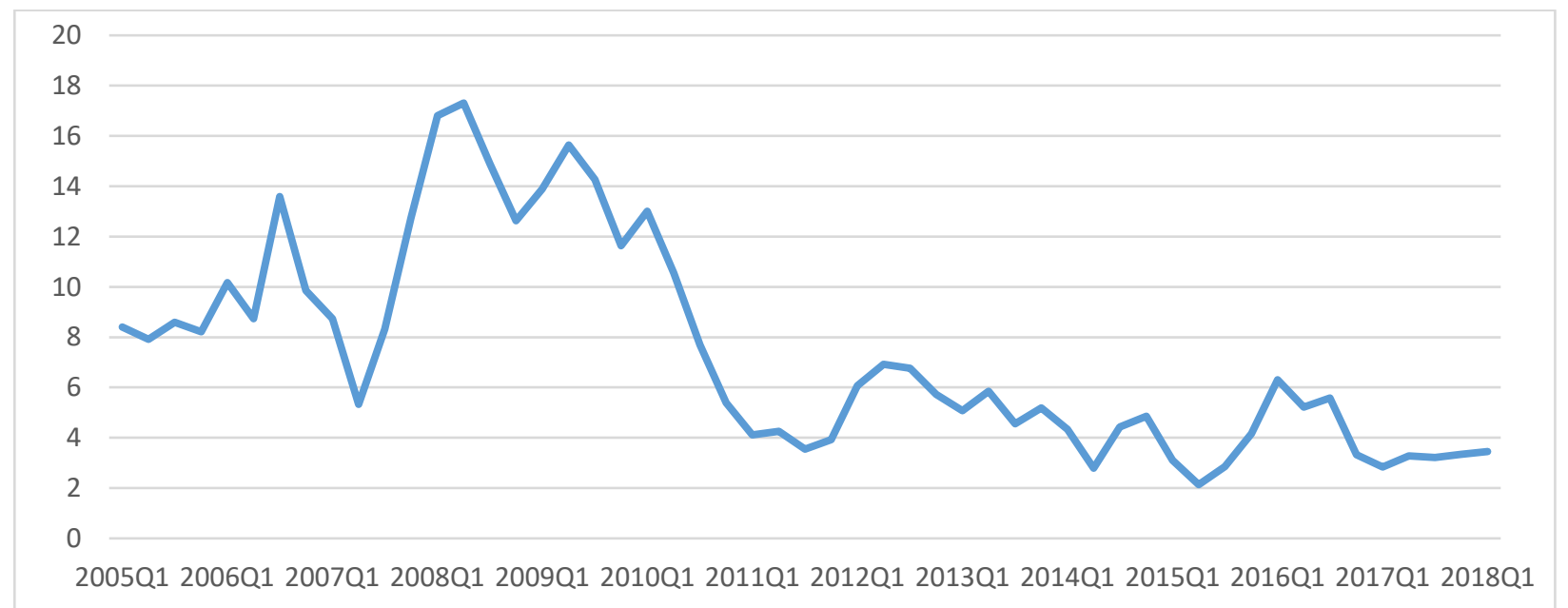

Source: STATA estimation 
Poland (graph 4): In the Polish economy, there has been a sharp increase in the value of the index since the end of 2007, with a very similar trajectory as in the Czech Republic. The peak of instability occurred already in the first quarter of 2008. After a slight decline in mid-2008, the index started to rise again to its peak in the first quarter of 2009 (24). After the stabilization, there was a further increase in the indicator values in 2011. A similar scenario can be observed between the years 2015 and 2016. Overall, however, after the 2010 crisis, there has been a stabilization that lasts until now.

\section{Graph 4: The CIFI results for the Poland}

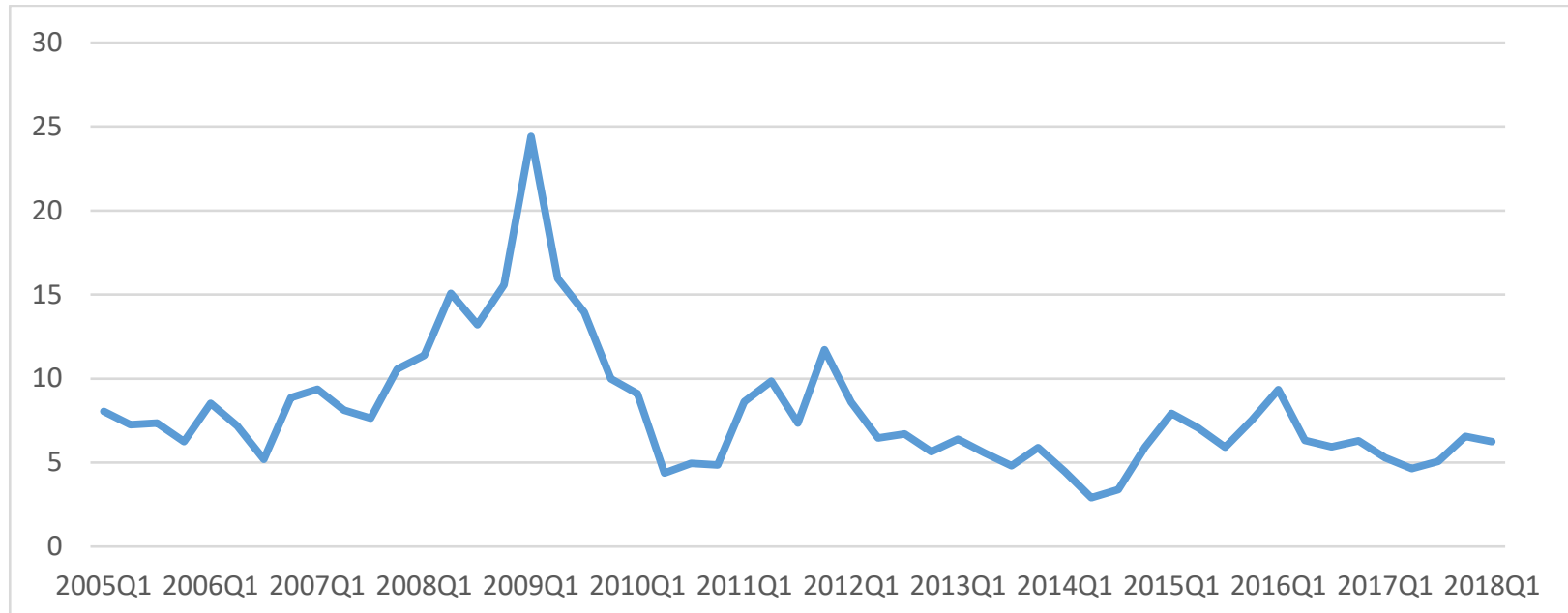

Source: STATA estimation

Hungary (graph 5): The CIFI indicator in Hungary indicates a growing instability in the economy a long time before the start of the Euro-American crisis. An index of around 10 was shown in Hungary already between the years 2005 - 2007. The peak of the gradual increase in instability occurred in 2008 Q1 (index value 26). However, the index shows the highest values after a slight decline in 2008, similar to the one in the Czech Republic and Poland in the first quarter of 2009 (32). The subsequent development is the most volatile of all V4 countries. Increased index values can be seen between the years $2011-2012$ and in 2016. 


\section{Graph 5: The CIFI results for the Hungary}

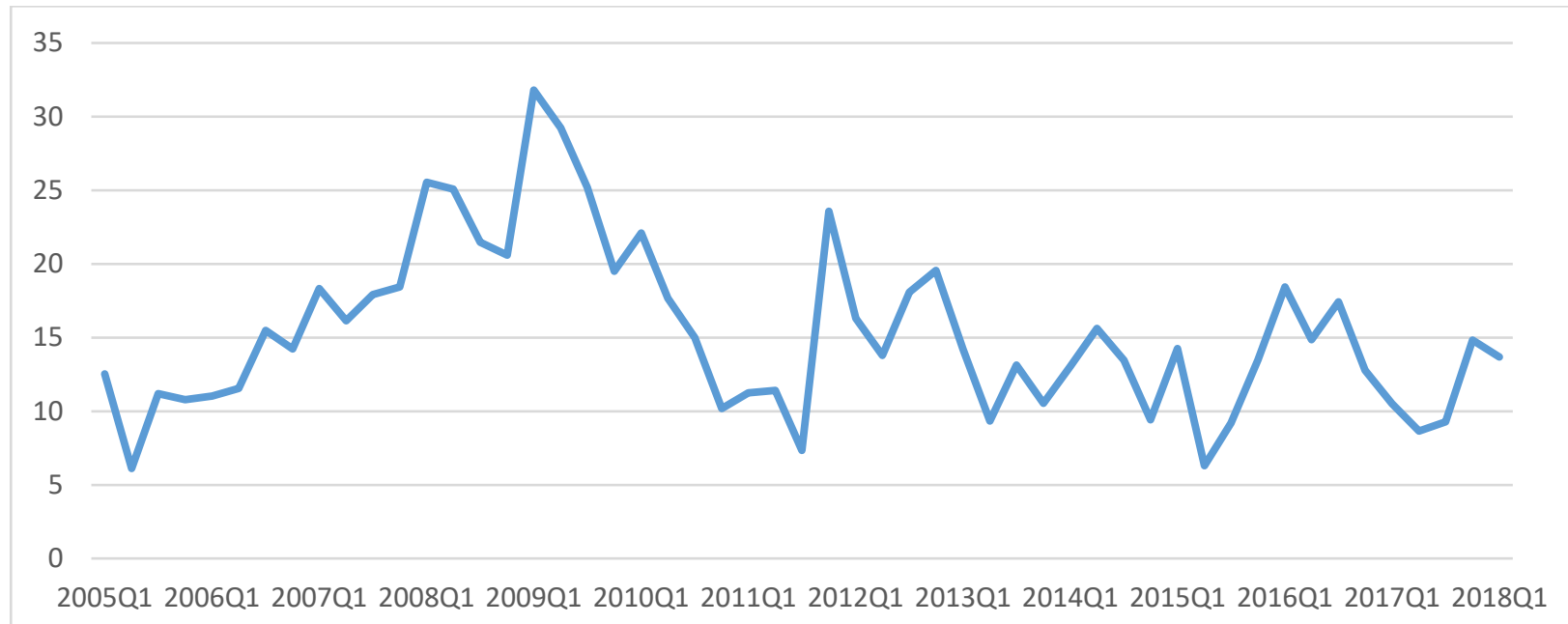

Source: STATA estimation

\section{Conclusion}

The Czech economy went through a very similar and synchronous development as Poland and Hungary over the monitored period, particularly in the 2008 and 2009 crisis years. This may show the similarity of all these three economies, their linking to foreign markets, and the fact that foreign investors perceive these countries as a part of one region. For all V4 countries, we can see an increase in instability already before the Euro-American crisis. However, Poland (24) and Hungary (32) have a significantly higher composite indicator than the Czech Republic (17) and Slovakia (17) at the level of instability. Current developments show a stabilization of financial conditions. An exception is the Czech economy, the values of its composite index are gradually growing and coming closer to those before 2008 .

It is interesting to compare these four countries with the development of financial conditions in Germany (see Graph 6). The index shows a sharp rise in instability in Germany in 2006 and 2007, in the third quarter of 2007 it is around 13. After the significant improvement in instability in the second half of 2008 , similarly to the V4 countries, re-culmination occurred. However, the highest values are reached only in 2009Q2 (the index is 17). Overall, after the crisis, the index has stabilized around the value number 5 , similarly to Slovakia and Poland, but unlike Hungary and the Czech Republic. 
Graph 6: The CIFI results for the Germany

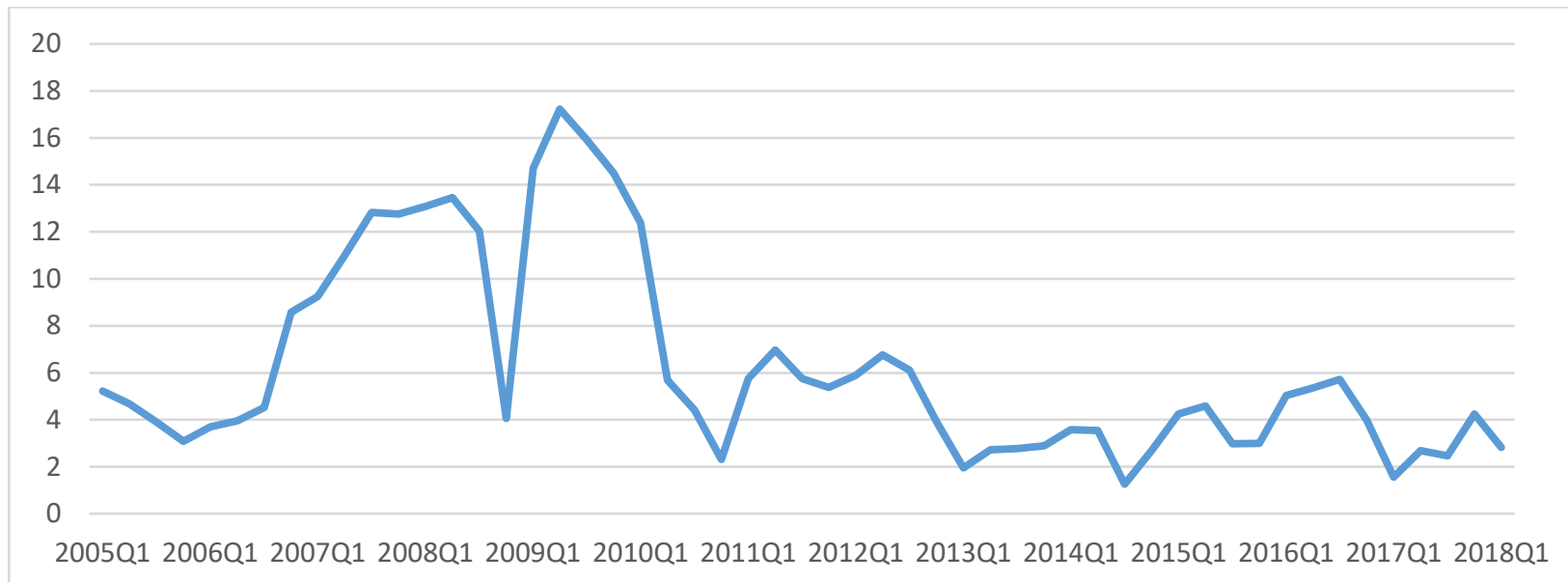

Source: STATA estimation

\section{Annexes}

Annex 1: Statistical description of the used variables

\begin{tabular}{r|rrrrr} 
Variable & Obs & Mean & Std. Dev. & Min & Max \\
\hline reserves & 655 & 30682.17 & 27747.04 & 16.809 & 148227.3 \\
reer & 485 & 88.32781 & 16.85685 & 42.89 & 117.76 \\
gdp & 363 & 1890751 & 2502719 & 0 & 1.01 e+07 \\
gdp_growth & 355 & .6650704 & 2.565177 & -15 & 8.7 \\
credit_GDP & 512 & 83.48047 & 28.85184 & 0 & 137.9 \\
CA & 417 & -20991.54 & 146508.8 & -620006 & 659401 \\
import & 453 & 1019108 & 1869077 & 2640.8 & 8177992 \\
import_GDP & 453 & 54.89669 & 19.86107 & 20.2 & 94.7 \\
export & 453 & 66350.63 & 96975.83 & 2051.3 & 395168 \\
export_GDP & 453 & 56.01082 & 20.61838 & 20.1 & 98.2 \\
CPI & 665 & 11.34921 & 65.28262 & -1.206758 & 1088.889 \\
PPI & 557 & 88.3203 & 18.4747 & 32.31012 & 120.9 \\
stock_index & 604 & 72.94983 & 46.03341 & 1.782198 & 206.3913 \\
house_price & 216 & 97.29204 & 10.0179 & 71.76 & 125.83 \\
IR_sr & 601 & 7.645996 & 8.455207 & -.3299667 & 53.26667 \\
IR_lr & 480 & 5.241168 & 2.516487 & -.1233333 & 11.71333
\end{tabular}

Source: own elaboration with SW STATA 


\section{Reference}

Abiad, A. (2003). Early-Warning Systems: A Survey and a Regime-Switching Approach. IMF Working Paper, No. 03/32.

Abiad, A., Balakrishnan, R., Brooks, P., Leigh D., Tytell, I. (2013). What's the Damage: Medium-term Output Dynamics after Financial Crises.

Babecký, J., Havránek, T., Matějů, J., Rusnák, M., Šmídová, K., Vašíček, B. (2011). Early Warning Indicators of Economic Crises: Evidence from a Panel of 40 Developed Countries. ČNB Working Paper series, No. 8.

Bordo, M. D. (2007). Growing up to Financial Stability. NBER Working Paper Series, No. 12993.

Borio, C., Lowe, P. (2002). Asset Prices, Financial and Monetary Stability: Exploring the Nexus. BIS Working Paper, No. 114.

Dell'Ariccia, G., Igan, D., Laeven, L., Tong, H. (2013). "Policies for Macrofinancial Stability: Dealing with Credit Booms and Busts," in S. Claessens, M. A. Kose, L. Laeven, and F. Valencia, eds., Financial Crises, Consequences, and Policy Responses, forthcoming.

Edison, H. (2003). Do Indicators of Financial Crises Work? An Evaluation of an Early Warning Systém. International Journal of Finance and Economics, Vol. 8(1), p. 11-53.

Frankel, J., Rose, K. (1996). Currency crashes in emerging markets: An empirical treatment. Journal of International Economics, Vol. 41 (3-4), p. 351-66.

Frankel, J., Saravelos, G. (2011) Can Leading Indicators Assess Country Vulnerability? Evidence from the 2008-09 Global Financial Crisis. Journal of International Economics, Vol. 87, p. 216-31.

GOLDSTEIN, M., TURNER, P. (1996). Banking Crises in Emerging Economies: Origins and Policy Options. BIS Economic Paper, October, No. 46.

Hawkins, J. Klau, M. (2000). Measuring potential vulnerabilities in emerging market economies. BIS Working Papers, No. 91.

HODRICK, R. J., PRESCOTT, E. C. (1997). Postwar U.S. Business Cycle: An Empirical Investigation. Journal of Money, Credit and Banking, No. 29, p. 1-16.

Illing, M., Liu, Y., 2006. Measuring financial stress in a developed country: an application to Canada. Journal of Financial Stability 2, 243-265.

Kaminsky, G., Reinhart, C. (1996). "The Twin Crises: The Causes of Banking and Balance-of-Payments Problems." Board of Governors of the Federal Reserve System, International Finance Discussion Papers 544.

Kaminsky, G., Lizondo, S., Reinhart, C. (1998). Leading Indicators of Currency Crisis. IMF Staff Papers, vol. 45, July.

Kaminsky, G., Reinhart, C. (1999). The twin crises: the causes of banking and balanceof- payments problems. American Economic Review, Vol. 89(3)

Kose, M., Loungani, P., Terrones, M. (2013). Global Recessions and Recoveries. IMF Working Paper

Laeven, L., Valencia, F. (2013). Systemic banking crises database. IMF Economic Review, Vol. 61, p. 225270.

Lall, S., Cardarelli, R., Elekdag, S. (2009). Financial Stress, Downturns, and Recoveries, IMF Working Paper No. 09/100.

Leaven, L., Valencia, F. (2008). Systemic Banking Crises: A New Database. IMF Working Paper, No. 08/224.

OECD (2008). Handbook on Constructing Composite Indicators: Methodology and User Guide. Paris: OECD Publishing. 
Slaný, M. (2010). Vývoj měnových podmínek v kontextu současné finanční krize. Ekonomické lity VŠEM, No. 2/2010, p. 45-57.

Vermeulen, R., Hoeberichts, M., Vašíček, B., Žigraiová, D., Šmídková, K., Haan, J. (2015). Financial stress indices and financial crises. DNB Working Paper, No. 469.

Vermeulen, R., Hoeberichts, M., Vašíček, B., Žigraiová, D., Šmídková, K., Haan, J. (2015). „Financial stress indices and financial crises" Working Paper No. 469, DNB. 